OPEN ACCESS

Edited by: Xavier Pochon,

Cawthron Institute, New Zealand

Reviewed by:

Patrick Cahill,

Cawthron Institute, New Zealand

Reimund Goss,

Leipzig University, Germany Jeremy Dahmen,

Lumen Bioscience, Inc., United States

${ }^{*}$ Correspondence:

Erwan Plouguerné

eplouguerne@hotmail.com

Bernardo A. P. da Gama

bapgama@gmail.com

tORCID:

Claire Hellio

orcid.org/0000-0003-2988-5183

Specialty section: This article was submitted to Marine Ecosystem Ecology, a section of the journal Frontiers in Marine Science

Received: 16 October 2019 Accepted: 13 February 2020

Published: 13 March 2020

Citation:

Plouguerné E, de Souza LM, Sassaki GL, Hellio C, Trepos R, da Gama BAP, Pereira $R C$ and

Barreto-Bergter E (2020)

Glycoglycerolipids From Sargassum vulgare as Potential Antifouling Agents. Front. Mar. Sci. 7:116. doi: 10.3389/fmars.2020.00116

\section{Glycoglycerolipids From Sargassum vulgare as Potential Antifouling Agents}

\author{
Erwan Plouguerné ${ }^{1,2 *}$, Lauro M. de Souza ${ }^{3}$, Guilherme L. Sassaki ${ }^{4}$, Claire Hellio ${ }^{5 \dagger}$, \\ Rozenn Trepos ${ }^{5}$, Bernardo A. P. da Gama ${ }^{1 *}$, Renato Crespo Pereira ${ }^{1,2}$ and \\ Eliana Barreto-Bergter ${ }^{6}$
}

\begin{abstract}
${ }^{1}$ Department of Marine Biology, Biology Institute, Universidade Federal Fluminense, Niterói, Brazil, ${ }^{2}$ Instituto de Pesquisas Jardim Botânico do Rio de Janeiro, Rio de Janeiro, Brazil, ${ }^{3}$ Instituto de Pesquisa Pelé Pequeno Príncipe, Rebouças, Curitiba, Brazil, ${ }^{4}$ Department of Biochemistry and Molecular Biology, Paraná Federal University, Curitiba, Brazil, ${ }^{5}$ Univ Brest, Laboratoire des Sciences de l'Environnement MARin (LEMAR), CNRS, IRD, Ifremer, France, ${ }^{6}$ Department of General Microbiology, Institute of Microbiology, Federal University of Rio de Janeiro, Rio de Janeiro, Brazil
\end{abstract}

Unraveling new environmentally friendly antifouling (AF) agents is one of the major quests currently facing marine biotechnology. Marine macroalgae represent a rich source of new compounds with promising biological properties, including AF activity, but most of the macroalgal compounds studied to date are terpenoids or polyphenolics. The aim of this work was to investigate the possible AF role played by a usually neglected class of marine natural products: glycolipids (monogalactosyldiacylglycerols MGDG, digalactosyldiacylglycerols - DGDG and sulfoquinovosyldiacylglycerols - SQDG) isolated from the Phaeophyceae Sargassum vulgare collected along the coast of south-eastern Brazil. Among the 18 extracts, fractions and sub-fractions tested, 3 subfractions demonstrated particularly promising AF activity toward the growth inhibition of marine bacteria and microalgae: F3III17, F4II70a, and F4II70b. The main compounds present in these fractions were identified as MGDG, DGDG, and SQDG, respectively. These results highlight the potential of glycoglycerolipids from $S$. vulgare as new promising antifouling agents.

Keywords: Sargassum vulgare, glycoglycerolipids, antifouling, microfouling, macroalgae

\section{INTRODUCTION}

Following the TBT ban in 2008, antifouling (AF) coatings containing several different biocides have been used as an alternative solution to prevent marine biofouling on immersed man-made surfaces. Most contemporary marine AF paints contain a $\mathrm{Cu}(\mathrm{I})$ based biocidal pigment (cuprous oxide or cuprous thiocyanate). Zinc oxide is also sometimes used as the principal biocidal pigment, but is more generally used in combination with $\mathrm{Cu}(\mathrm{I})$ as a booster. The $\mathrm{AF}$ properties of these modern formulations are further enhanced by the addition of one or more secondary or booster co-biocides. These include zinc and copper pyrithione, Irgarol 1051, chlorothalonil, TMCS pyridine, SEA-NINE 211, ziram, zineb, dichlofluanid and diuron (Turner, 2010). The general use of these booster 
biocides in copper-based AF paints has resulted in contamination of the marine environment and raised concerns about their negative impacts on marine communities (Dafforn et al., 2011). As an example, many studies already report hazardous concentrations of Irgarol 1051, Diuron and their degradation products in estuarine waters (Tsunemasa and Yamazaki, 2014; Kim et al., 2015). These herbicides represent an environmental issue due to their high toxicity toward marine organisms, particularly regarding to marine microalgae (Sjollema et al., 2014). In response to such ecological threat, the use of Diuron and Irgarol 1051 has already been restricted or banned in some European countries since the early 2000s (Readman, 2006; Zhou, 2008; Silkina et al., 2009; Sapozhnikova et al., 2013). Copper-based paints themselves represent an environmental problem, and $\mathrm{Cu}$ contamination due to $\mathrm{AF}$ paints in costal environments is now a global issue. Indeed, dissolved copper concentrations exceeding 3.1 parts per billion (standard set by the United States Environmental Protection Agency) has been proved to affect various life stages of marine invertebrates such as scallops, mussels, oysters, sea urchins, and crustaceans (Coglianese and Martin, 1981; Martin et al., 1981; Calabrese et al., 1984; Lee and Xu, 1984; Lussier et al., 1985; Gould et al., 1988; MacDonald et al., 1988; Stromgren and Nielsen, 1991; Carson et al., 2009). Therefore, new solutions are needed to develop environmentally friendly alternatives to TBT, biocides or copper-based paints. In the United States, Western states are leading the campaign against copper AF paints: Washington became the first state to ban copper-based paints containing more than $0.5 \%$ copper beginning in 2020 (for recreational boats under $20 \mathrm{~m}$ ).

Marine organisms are naturally exposed to biofouling and the colonization of their surface can result in diverse physiological issues, and ultimately in the death of the host (Wahl, 1989). In order to prevent such colonization, marine organisms have developed different defensive strategies, including the production of AF compounds. Among marine organisms, macroalgae have been extensively studied as a potential source of AF agents. Terpenoids and phenolic compounds represent the major classes of AF compounds that were described in marine macroalgae (Da Gama et al., 2014).

Usually neglected, glycolipids are another class of interesting compounds produced mainly by marine organisms (Zhang et al., 2014) and have recently gained interest due to their many biological activities (Da Gama et al., 2014). Glycolipids from macroalgae have been reported to exhibit antiviral, anticancer, antiherbivory, antibacterial and antimicroalgal activities (Plouguerné et al., 2014). Galactoglycerolipids from the brown alga Fucus vesiculosus inhibit feeding by sea urchins at naturally observed concentrations (Deal et al., 2003). Slattery and Lesser (2014) highlighted the allelopathic role played by a galactoglycerolipid isolated from the brown alga Lobophora variegata. Kiran et al. (2014) highlighted the antimicrobial activity of a glycolipid biosurfactant produced by the sponge-associated marine actinobacterium Brachybacterium paraconglomeratum MSA21. Another glycolipid surfactant, composed of glucose and palmitic acid, produced by a tropical strain of the bacteria Serratia marcescens exhibited
AF activity against the marine bacterium Bacillus pumilus (Dusane et al., 2011). Plouguerné et al. (2010) highlighted antimicrofouling activity of glycolipids from the brown seaweed Sargassum muticum.

In marine macroalgae, glycolipids are represented by three major distinct classes of compounds: monogalactosyldiacylglycerols (MGDG), digalactosyldiacylglycerols (DGDG) and sulfoquinovosyldiacylglycerols (SQDG). In this study, glycolipids from the Brazilian Phaeophyceae Sargassum vulgare were extracted and a bioprospecting approach was used to identify antifouling activity and perform fractionation of the extract. Three sub-fractions demonstrated particularly promising antifouling activity toward the growth inhibition of marine bacteria and microalgae involved in the biofouling process. The main compounds present in theses fractions were identified as, respectively, MGDG, DGDG, and SQDG.

\section{MATERIALS AND METHODS}

\section{Biological Material}

Thalli of S. vulgare were collected by free diving in the shallow subtidal zone on the Ilha de Itacuruçá, a large nearshore island inside Sepetiba Bay (Mangaratiba district, Rio de Janeiro State, Southeastern Brazil, Southwestern Atlantic $\left.22^{\circ} 56^{\prime} \mathrm{S}, 43^{\circ} 52^{\prime} \mathrm{W}\right)$. After collection, specimens of $S$. vulgare were immediately transferred to the laboratory in isothermic boxes, where they were gently washed in seawater, sorted, and carefully cleaned from epiphytes. Thalli were then freeze-dried and further ground to a fine powder before performing extraction.

\section{Extraction and Lipid Fractionation}

The powder obtained from freeze-dried S. vulgare specimens was successively extracted at room temperature with chloroform/methanol $2: 1$ and $1: 2 \quad(\mathrm{v} / \mathrm{v})$, according to methodology previously published (Barreto-Bergter et al., 2011; de Souza et al., 2012). After filtration, the extracts were combined, dried and the crude lipid extract was partitioned according to Folch et al. (1957). Lipids recovered from the lower phase were fractionated on a silica gel column (Silica gel 60 [0.063-0.200 mm]; Merck $\left.{ }^{\circledR}\right)$, which was eluted with chloroform, acetone and methanol, giving rise to fractions F1-F4 (Figure 1). Being the most biologically active fractions, fractions F3 and F4 were selected for further purification (Table 1). Fraction F3 was purified on a silica gel column eluted with chloroform/methanol with increasing concentrations of methanol (100, 95:5, 90:10, $80: 20,70: 30,50: 50, \mathrm{v} / \mathrm{v})$ and finally with $100 \%$ methanol. Eighty-two sub-fractions were obtained which were then pooled according to their HPTLC profiles (HPTLC Silica gel $60 \mathrm{~F}_{254}$ $\left.\operatorname{Merck}^{\circledR}\right)\left(\mathrm{CHCl}_{3} / \mathrm{MeOH} / \mathrm{NH}_{4} \mathrm{OH}[2 \mathrm{~N}] ; 40 / 10 / 1\right)$, resulting in five final fractions: F3I1, F3I26, F3I31, F3I48, and F3I60. Purification of the fraction F3I31 was then performed on a second silica gel column sequentially eluted with chloroform/methanol with increasing concentrations of methanol $(95: 5,90: 10 \mathrm{v} / \mathrm{v})$. Finally, the column was washed with $100 \%$ methanol. The purification process led to fifty-nine sub-fractions. After 


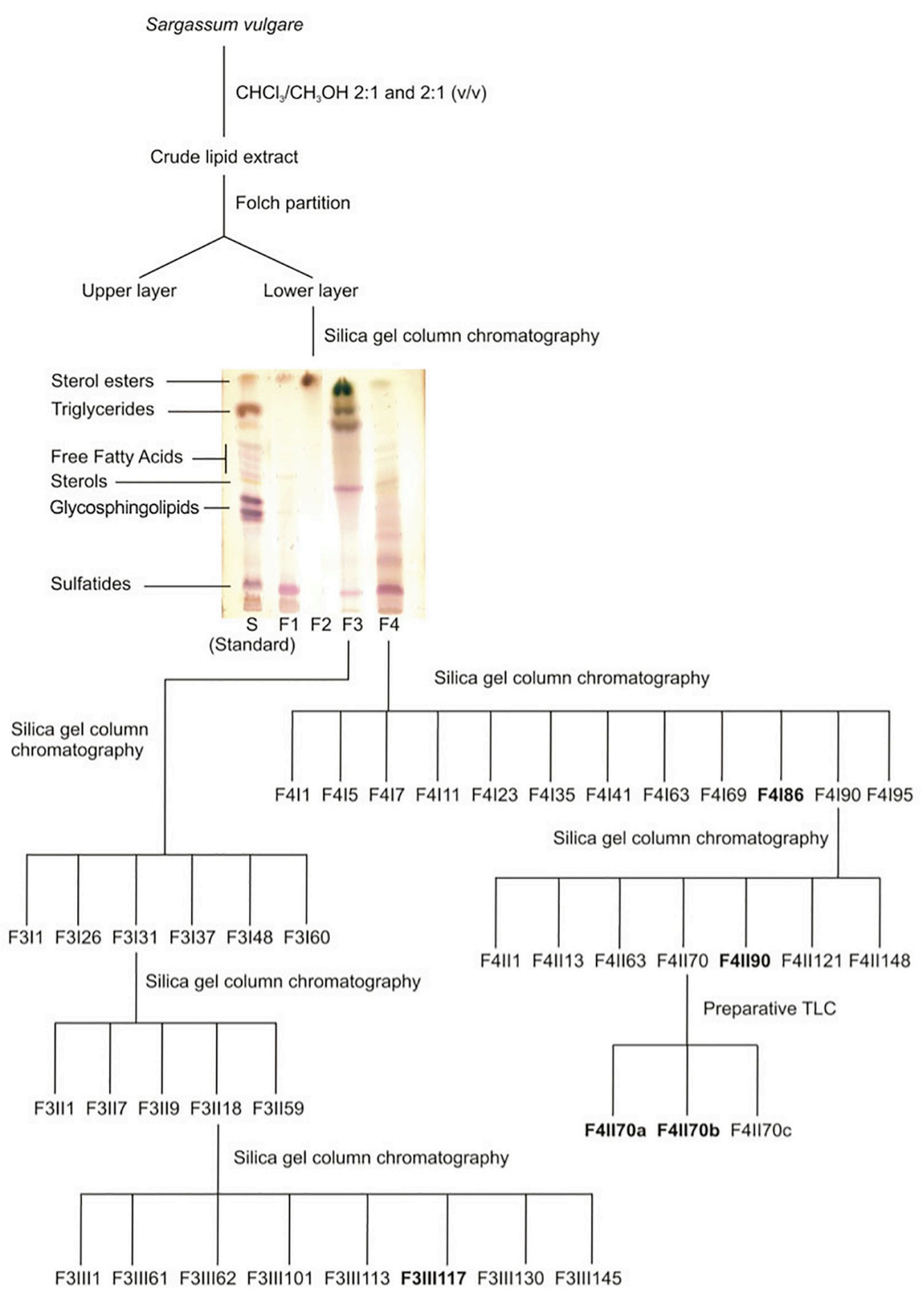

FIGURE 1| Resumed purification protocol of glycolipids from S. vulgare.

examining their TLC profiles, the fractions were pooled and their number reduced to five: F3II1, F3II7, F3II9, F3II18, and F3II59. A third silica gel column was used to purify the F3II18 fraction. The elution of fraction F3II18 by 100\% chloroform followed by chloroform/methanol (95/5) and finally chloroform/methanol (95/5) led to one hundred and fifty-one fractions. These fractions were pooled according to their TLC profiles, resulting in eight final fractions: F3IIIl,
F3III61, F3III62, F3III101, F3III113, F3III117, F3III130, F3III145. Fraction F4, eluted with methanol and enriched in sulfatides, was further purified on a silica gel column, which was sequentially eluted with chloroform/methanol with increasing concentrations of methanol (95:5, 90:10, 80:20, $50: 50 \mathrm{v} / \mathrm{v}$ ) and finally $100 \%$ methanol. The resulting fractions were combined in twelve final fractions. Fraction F4I86 was guarded for further analyses and fraction F4I90, eluted with 
TABLE 1 | Antifouling activity of extract, fractions and sub-fractions from S. vulgare against bacteria (Pseudoalteromonas elyakovii, Halomonas marina, Shewanella putrefaciens, and Polaribacter irgensii) and microalgae (Chlorarachnion reptans, Pleurochrysis roscoffensis, Exanthemachrysis gayraliae, Cylindrotheca closterium, and Navicula jeffreyi).

\begin{tabular}{|c|c|c|c|c|c|c|c|c|c|}
\hline \multirow[b]{2}{*}{ Fractions } & \multicolumn{4}{|c|}{ Bacteria } & \multicolumn{5}{|c|}{ Microalgae } \\
\hline & P. elyakovii & P. irgensii & H. marina & S. putrefaciens & C. reptans & P. roscoffensis & E. gayraliae & C. closterium & N. jeffreyi \\
\hline Crude extract & 1 & 10 & 1 & 1 & 0.1 & 1 & 0.1 & 1 & 1 \\
\hline F1 & $>10$ & $>10$ & $>10$ & $>10$ & $>10$ & $>10$ & 0.1 & 0.1 & 0.1 \\
\hline $\mathrm{F} 2$ & $>10$ & $>10$ & $>10$ & $>10$ & $>10$ & $>10$ & $>10$ & $>10$ & $>10$ \\
\hline F3 & 1 & $>10$ & 1 & 1 & 1 & 1 & 0.1 & 0.1 & 0.1 \\
\hline $\mathrm{F} 4$ & 1 & 10 & 10 & 1 & 1 & 1 & 0.1 & 0.1 & 0.1 \\
\hline F3I26 & $>10$ & $>10$ & $>10$ & $>10$ & $>10$ & $>10$ & $>10$ & $>10$ & $>10$ \\
\hline F3I60 & 1 & $>10$ & 1 & 1 & 1 & 1 & 0.1 & 0.1 & 0.1 \\
\hline F3ll18 & 0.1 & $>10$ & 0.1 & 0.1 & 0.1 & 0.1 & 0.01 & 0.01 & 0.01 \\
\hline F3III117 & 0.01 & $>10$ & 0.01 & 0.01 & 0.01 & 0.01 & 0.01 & 0.01 & 0.01 \\
\hline F4l11 & 1 & 10 & 10 & 1 & 0.1 & 0.1 & 0.01 & 0.01 & 0.01 \\
\hline F4I63 & 10 & $>10$ & $>10$ & 10 & 10 & 10 & 10 & 10 & 10 \\
\hline F4I69 & 10 & $>10$ & $>10$ & 10 & 1 & 1 & 1 & 1 & 1 \\
\hline F4I86 & 1 & $>10$ & $>10$ & 1 & 1 & 1 & 1 & 1 & 1 \\
\hline F4II70 & 0.1 & $>10$ & $>10$ & 0.1 & 0.1 & 0.1 & 0.1 & 0.1 & 0.1 \\
\hline F4II90 & 0.1 & $>10$ & $>10$ & 0.1 & 1 & 1 & 1 & 1 & 1 \\
\hline F4II70a & 0.01 & $>10$ & $>10$ & 0.01 & 0.01 & 0.01 & 0.01 & 0.01 & 0.01 \\
\hline F4II70b & 0.1 & $>10$ & $>10$ & 0.1 & 0.01 & 0.01 & 0.01 & 0.01 & 0.01 \\
\hline F4II70c & 1 & $>10$ & $>10$ & 1 & 0.1 & 0.1 & 0.1 & 0.1 & 0.1 \\
\hline
\end{tabular}

Minimum inhibitory concentrations (MICs) are expressed in $\mu \mathrm{g} / \mathrm{mL}$.

80/20 chloroform/methanol, and purified on a second silica gel column yielding a purified sulfolipid fraction, F4II90. The F4II70 fraction was further purified using preparative TLC $(\mathrm{CHCl} 3 / \mathrm{MeOH} / \mathrm{H} 20 ; 30 / 17.5 / 3.5)$, leading to three new fractions: F4II70a, F4II70b, and F4II70c.

\section{Mass Spectrometry (MS)}

The MS analysis was carried out in an electrospray ionization mass spectrometry (ESI-MS), model Quattro-LC (Waters), with a triple-quadrupole mass analyzer, operating at atmospheric pressure ionization (API), assisted by a syringe pump (KD Scientific) for sample infusion. Nitrogen was used as nebulizing and desovation gas and the ionization energies were $50 \mathrm{~V}$ on the cone and $2 \mathrm{kV}$ on the capillary, operating in the negative ionization mode. The second stage tandem-MS was obtained by collision induced dissociation mass spectrometry (CID-MS) using argon as collision gas with collision energies ranging between 35-60 eV. The samples were prepared in $\mathrm{MeOH}$ at $1 \mathrm{mg} / \mathrm{mL}$, then diluted to $0.1 \mathrm{mg} / \mathrm{mL}$ in $\mathrm{MeOH}-\mathrm{H} 2 \mathrm{O}(7: 3, \mathrm{v} / \mathrm{v})$ and directly infused into ESI source, at a flow rate of $10 \mu \mathrm{L} / \mathrm{min}$ (de Souza et al., 2012).

\section{Antibacterial Assays}

The crude extract, the chromatographic fractions and subfractions were tested for their inhibitory activity against the growth of four strains of biofilm-forming marine bacteria: Pseudoalteromonas elyakovii (ATCC 700519), Halomonas marina (ATCC 25374), Shewanella putrefaciens (ATCC 8071) and Polaribacter irgensii (ATCC 700398) (Trepos et al., 2014; Zhou et al., 2014; Hellio et al., 2015). Bacterial strains were maintained on agar plates [LB medium, $\mathrm{NaCl}$ (35 g/l), agar (15\%)].
Experiments were run as previously described by Maréchal et al. (2004), and each treatment and control (seawater and SEA-NINE) was repeated six times. The crude extract and fractions were incubated with each bacterial strain (2.108 cells/ml) in 96-well plates (VWR) in LB medium (Luria Hinton Broth, Sigma, Andover, United Kingdom), supplemented with $\mathrm{NaCl}(35 \mathrm{~g} / \mathrm{l})$, at $30^{\circ} \mathrm{C}$ for $72 \mathrm{~h}$. After incubation, the intensity of growth in presence of the tested compounds and control was compared by measuring the optical density at $620 \mathrm{~nm}$. Results were expressed as MIC (minimum inhibitory concentration) values.

\section{Anti-Microalgal Assays}

The crude extract and the fractions were tested for their inhibitory activity against the benthic phase of five model strains of marine microalgae obtained from Algobank (University of Caen Normandy, France): Chlorarachnion reptans (AC133), Pleurochrysis roscoffensis (AC32), Exanthemachrysis gayraliae (AC15), Cylindrotheca closterium (AC170), and Navicula jeffreyi (AC181) (Son et al., 1992; Trepos et al., 2014). All microalgal cultures and assays were kept under controlled conditions in a constant temperature chamber at $18 \pm 2^{\circ} \mathrm{C}$, and photoperiod of 15:9 light:dark (54 $\mu \mathrm{mol}$ photons $\mathrm{m}^{-2} \mathrm{~s}^{-1}$ cool-white fluorescent lamp). Stock of strains was kept on agar plates (F/2, agar 12.5\%) (Guillard and Ryther, 1962). Experiments were carried out in six replicates and run as previously described in Tsoukatou et al. (2002): $100 \mu \mathrm{l}$ of a culture at $0.4 \mu \mathrm{g} / \mathrm{ml}$ of chlorophyll a were introduced in 96-well plates containing the crude extract or fractions. SEA-NINE was used as control. SEANINE is a broad spectrum antifouling agent active at inhibiting growth and settlement of marine fouling organisms (bacteria, 
fungi, algae, barnacles) on submerged surfaces (Jacobson and Willingham, 2000). The biocidal ingredient in SEA-NINE is the 4,5-dichloro-2-n-octyl-4-isothiazolin-3-one (DCOIT). DCOIT reacts with the proteins of organisms that come in contact with the coating surface. Fouling organisms initiate specific physiological activities involved in attaching to solid surfaces that are disrupted by DCOIT. As a result the organisms do not successfully colonize the treated surfaces and biofouling is minimized (Chen and Lam, 2017). The inoculated plates were grown for 5 days under constant light exposure $(140 \mu \mathrm{mol}$ $\mathrm{m}^{-2} \mathrm{~s}^{-1}$ ) at $20^{\circ} \mathrm{C}$. After the incubation, the microplates were centrifuged at $4,100 \mathrm{rpm}$ for $10 \mathrm{~min}$ at $4^{\circ} \mathrm{C}$ using a Beckman Coulter Allegra 25R centrifuge and subsequently emptied. $100 \mu \mathrm{L}$ of $100 \%$ methanol was added to each well to liberate chlorophyll a. The pigment concentration was quantified employing the fluorimetric method (Chambers et al., 2011). Results were expressed as MIC (minimum inhibitory concentration) values. The chlorophyll a determination was performed according to the methods described by Bovio et al. (2019). Calibration curves were performed for each microalgae (data not presented) in order to correlate the number of cells (measured using a Malassez cell) and chlorophyll a concentrations measured by different techniques (with or without sonication, different solvents) according to the methods described by Hosikian et al. (2010).

\section{RESULTS}

\section{Antifouling Activity}

All results concerning the antibacterial activity of $S$. vulgare crude extract, fractions and sub-fractions are presented in Table $\mathbf{1 .}$ Among the 18 extract, fractions and sub-fractions tested, 3 sub-fractions demonstrated particularly high antifouling activity: F3III117, F4II70a, and F4II70b.

Fraction F3III117 inhibited the growth of all the bacterial and microalgal strains tested with MIC values of $0.01 \mu \mathrm{g} / \mathrm{mL}$, with the exception of $P$. irgensii (MIC $>10 \mu \mathrm{g} / \mathrm{mL}$ ). In relation to S. putrefaciens, H. aquamarina, and P. elyakovii, F3III117 displayed higher antibacterial activity than the commercial antifouling product SEA-NINE.

Fraction F4II70a was the second most active fraction and inhibited the growth of 7 of the 9 strains tested, with a MIC of $0.01 \mu \mathrm{g} / \mathrm{mL}$; the bacteria $P$. irgensii and $H$. marina were inhibited with a MIC $>10 \mu \mathrm{g} / \mathrm{mL}$. The antibacterial activity of F4II70a was similar to the commercial biocide SEA-NINE. The third most active fraction was the fraction F4II70b, which inhibited the growth of all the microalgae strains, 5 of them with an MIC of $0.01 \mu \mathrm{g} / \mathrm{mL}$.

Further chemical analyses were carried out in order to identify the main compounds present in these three fractions.

\section{Chemical Analysis}

\section{Fraction F3III117}

In order to improve the positive ion detection of neutral lipids, $\mathrm{Li}+(\mathrm{LiCl})$ was added in the sample solvent, giving the molecules as lithiated ions. The fraction F3III117 gave in MS1 a predominant ion with $\mathrm{m} / \mathrm{z} 778.13[\mathrm{M}+\mathrm{Li}]+$. This predominant ion was fragmented by CID-MS giving rise to characteristic spectrum of neutral glyceroglycolipids (Figure 2). The ions at $\mathrm{m} / \mathrm{z} 521$ and 481 were consistent with loss of a palmitic acid (C16:0) from the sn-1 position and a nonadecenoic acid (C19:1) from the sn-2 position, respectively. The fragmentions from glycan moiety appeared at $\mathrm{m} / \mathrm{z} 227.1$ and 169.0, thus being consistent with the fragmentation partner of a monogalactosyldiacylglycerol (MGDG).

\section{Fraction F4II70a}

In order to improve the positive ion detection of neutral lipids, $\mathrm{Na}+(\mathrm{NaCl})$ was added in the sample solvent, giving the molecules as sodiated ions. The fraction F4II70a gave in MS1 a predominant ion with $\mathrm{m} / \mathrm{z} 912.8[\mathrm{M}+\mathrm{Na}]+$. This ion gave fragments $\mathrm{m} / \mathrm{z} 744.8, \mathrm{~m} / \mathrm{z} 331.2$ and $\mathrm{m} / \mathrm{z}$ 169.2, characteristics of a DGDG (Figure 2). The fragments $\mathrm{m} / \mathrm{z} 657.4$ and $\mathrm{m} / \mathrm{z}$ 659.4 correspond to the loss of a palmitic acid (C16:0) in sn1 position and of a palmitoleic acid $(\mathrm{C} 16: 1)$ in sn-2 position, respectively (Figure 3).

\section{Fraction F4II70b}

The spectrum obtained in negative MS1 from fraction F4II70b exhibited ion with $\mathrm{m} / \mathrm{z} 835.9[\mathrm{M}-\mathrm{H}]$ - as the most abundant. In order to confirm the structures, the ion at $\mathrm{m} / \mathrm{z} 835.9$ was fragmented by the second stage tandem-MS. The ion gave fragments at $\mathrm{m} / \mathrm{z} 224.7,165.1,152.8,95.4$, and 81.3 characteristic of the 6-deoxy-6-sulfono-hexosyl residue of the SQDG (Figure 3). The fragments at $\mathrm{m} / \mathrm{z} 579.0$ (M-C16:0 from the sn-2 position), 537.6 (M-C19:0 from the sn-1 position), 224.7, $165.1,152.8,95.4$, and 81.3 , as indicated in the fragmentation pathway, is consistent with a SQDG structure, esterified by one palmitic acid (C16:0) in sn-2 position and one non-adecylic acid (C19:0) in sn-1 position (Figure 4).

\section{DISCUSSION}

Macroalgae are recognized targets of increasing interest as promising natural sources for the discovery of new AF compounds exhibiting high performance and non-polluting nature (Da Gama et al., 2008; Dafforn et al., 2011). In general, the AF chemicals from green, brown and red seaweeds are dominated by terpenoids and halogenated compounds (Plouguerné et al., 2014). Few studies focused on the biological and ecological roles of glycolipids or how such compounds may act as defensive agents toward herbivores or fouling pressure (Plouguerné et al., 2014). In the present study, total lipids extracted with chloroform/methanol were used to obtain glycolipids of the brown seaweed $S$. vulgare and they have been evaluated as antifoulants against different biofouling bacteria and microalgae in laboratory assays.

Analysis by High Performance Thin Layer Chromatography, followed by Mass Spectrometry, enabled us to identify 3 classes of glycolipids present in the lipid fractions of the extract from $S$. vulgare: monogalactosyldiacylglycerols (MGDG), digalactosyldiacylglycerols (DGDG) and sulfoquinovosyldiacylglycerols (SQDG). Glycolipids occur 


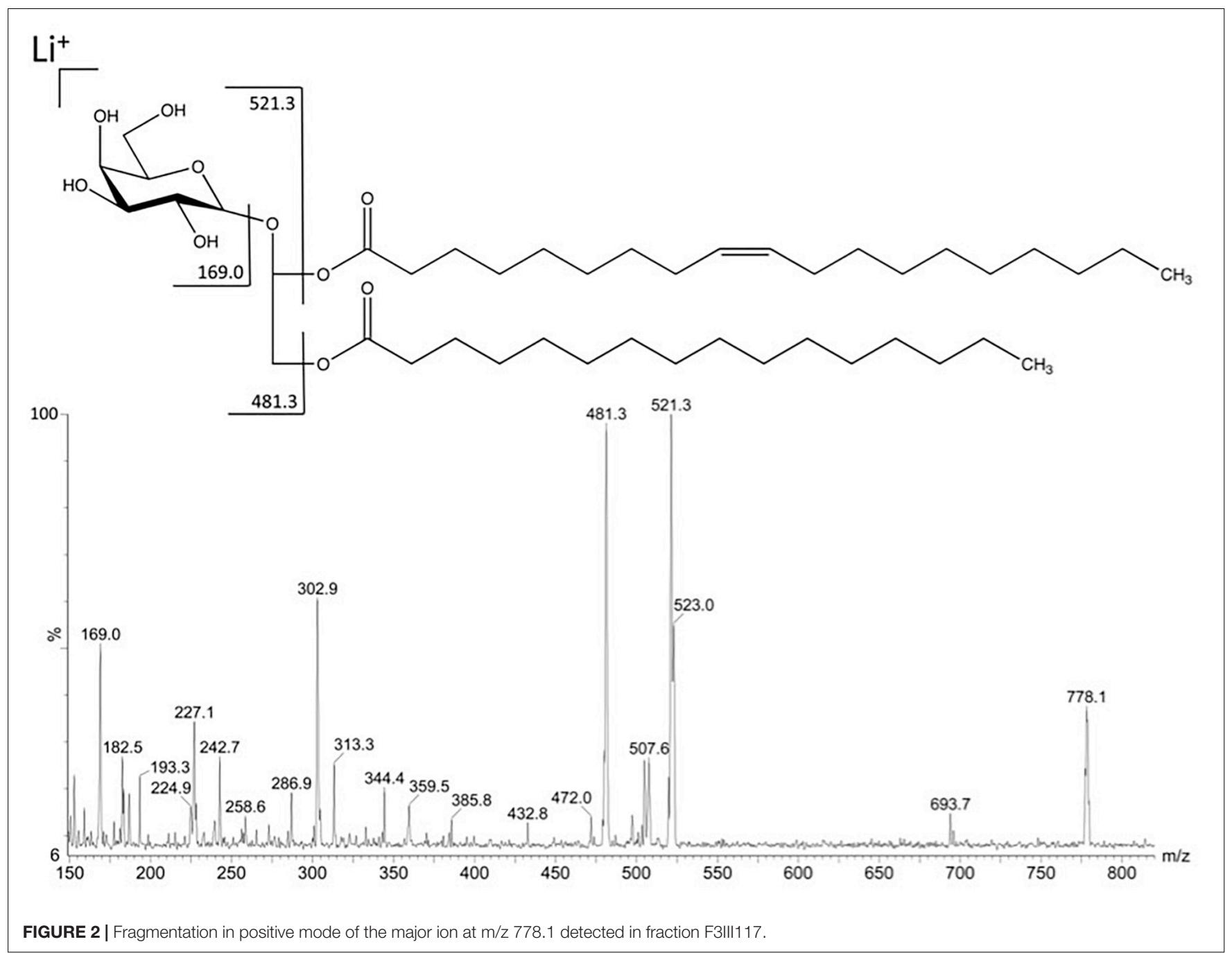

in all eucaryotic photosynthetic organisms and cyanobacteria where they constitute the main component of the thylakoid membrane in chloroplasts (Kobayashi, 2016). Thus, glycolipids are not directly exposed at the surface of the thalli but rather present within the cell. Some may argue that such localization of glycolipids may prevent them to act as antifouling compounds in vivo. However, a growing number of evidence demonstrates that a wide variety of epibiontes may damage the thallus surface of the algae (Leonardi et al., 2006; Muñoz and Fotedar, 2009). Therefore, antifouling activity may not be limited to molecules present directly at the surface of the algae but may be also related to within-thallus compounds. Glycoglycerolipids occur widely in brown seaweeds, mainly in Sargassum species (Son et al., 1992; Kim et al., 2007), and our results expand the knowledge of glycolipids in these marine organisms and reiterates the importance of these chemicals in Sargassum species.

The results from the MS analysis show the presence of a C19 fatty acid in majoritary MGDG and SQDG. In higher plants unsaturated $\mathrm{C} 16$ and $\mathrm{C} 18$ fatty acids are found as principal components of the glycolipids. In diatoms longer chain fatty acids can be integral part of the glycolipids, however, like the higher plant fatty acids, these usually contain an even number of carbon atoms, i.e., C20, C22 or even C24. Green algae glycolipids contain a high ratio of C18/C20 polyunsaturated fatty acids, whereas red and brown algae show a high ratio of $\mathrm{C} 20 / \mathrm{C} 18$ polyunsaturated fatty acids (Kalisch et al., 2016).

In addition to the chemical findings, we also verified a significant AF activity of the fractions containing glycolipids by inhibiting the growth of biofilm bacteria and microalgae. In fact, among the 18 extract, fractions and sub-fractions tested, the sub-fractions containing glycolipids exhibited higher AF activity, in the following decreasing sequence of action: $M G D G>D G D G>S Q D G$. Our results expand the few biological/ecological activities for glycolipids from brown seaweeds, previously known to inhibit feeding by sea urchins at natural concentration in Fucus vesiculosus (Deal et al., 2003), and play allelopathic function for Lobophora variegata (Slattery and Lesser, 2014). It also confirms previous study by Plouguerné et al. (2010), which highlighted antimicrofouling activity of glycolipids from the brown seaweed Sargassum muticum. It is noteworthy that some fractions were even more effective than commercial antifouling compounds currently in use. 

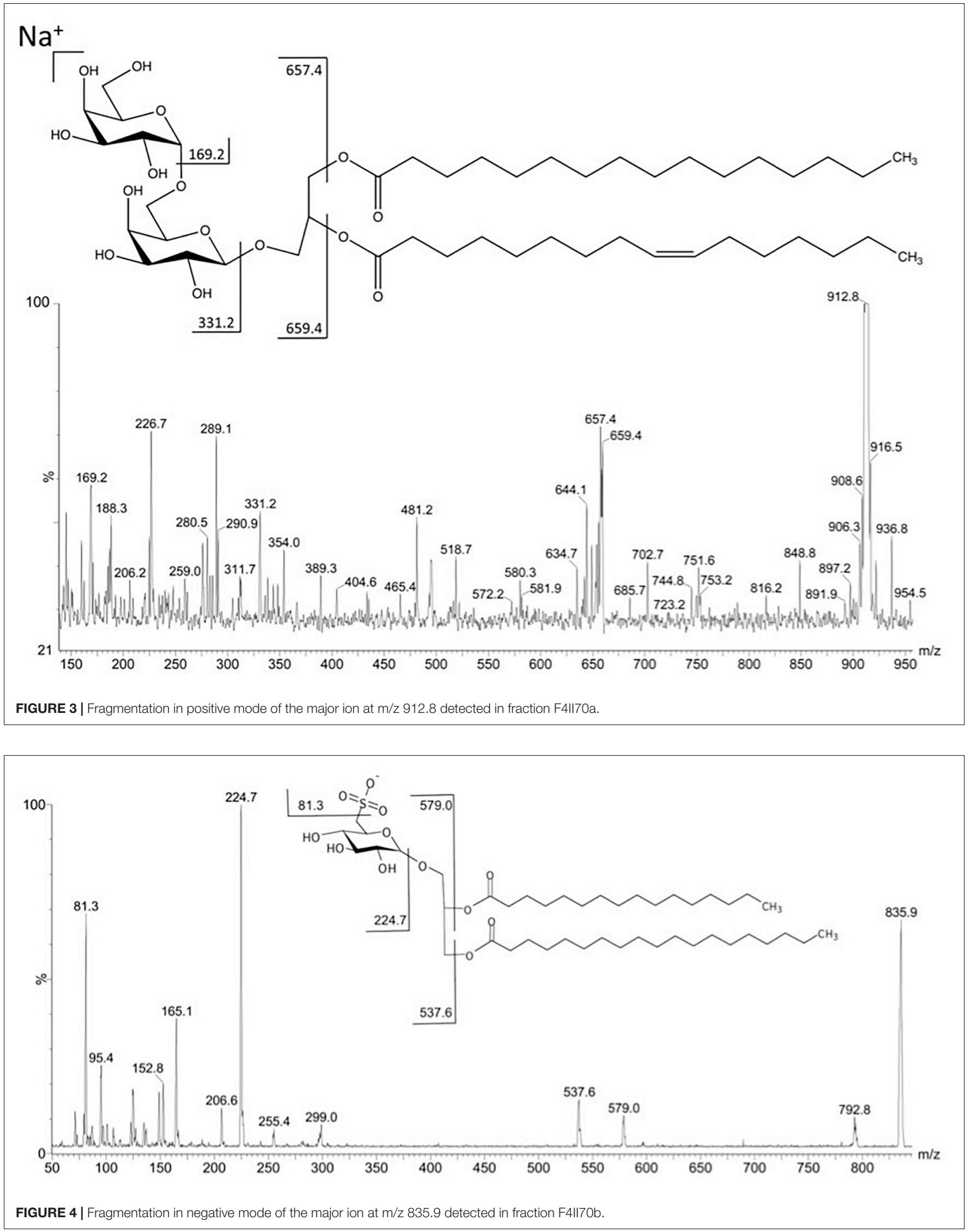
The establishment of marine biofouling comprises two distinct steps: the initial settlement and development of microorganisms, such as bacteria, fungi and microalgae to form the microfouling and the further colonization by macroorganisms, such as barnacles, tubeworms and mussels which constitute the macrofouling (Wahl, 1989; Holmstrom and Kjelleberg, 1994; Callow and Callow, 2002; Dobretsov et al., 2006). In general, it is accepted that initial establishment of microorganisms (microfouling) can facilitate the subsequent stage, the settlement of the macroorganisms (Qian et al., 2007). Thus, prevention of microfouling settlement appears to be fundamental in order to limit further colonization by macroorganisms (Hanssen et al., 2014). The antifouling activity of glycolipids from S. vulgare highlighted in our study is relevant since the microorganisms tested here are representative of microfouling species present in both estuarine and marine environments (Jellali et al., 2013).

The search for environmentally friendly antifouling solutions is a pressing topic of great ecological relevance. However, research on AF agents from seaweeds usually does not consider the supply problem. Like most seaweed metabolites, only limited quantities of pure glycoglycerolipids can be obtained from natural sources. In addition, it is difficult to isolate them as single compounds (Cateni et al., 2007). However, examples of glycoglycerolipid total synthesis already exist, which may represent a sustainable alternative in regard to natural resource exploitation (Deal et al., 2003; Zhang et al., 2014). Further studies are necessary to evaluate the antifouling efficiency of these chemicals against macrofouling, preferably under field conditions, in order to confirm the settlement trends observed in the laboratory.

\section{REFERENCES}

Barreto-Bergter, E., Sassaki, G. L., and Souza, L. M. (2011). Structural analysis of fungal cerebrosides. Front. Microbiol. 2:239. doi: 10.3389/fmicb.2011.00239

Bovio, E., Fauchon, M., Toueix, Y., Mehiri, M., Varese, G. C., and Hellio, C. (2019). The sponge-associated fungus Eurotium chevalieri MUT 2316 and its bioactive molecules: potential applications in the field of antifouling. Mar. Biotechnol. 6, 743-752. doi: 10.1007/s10126-019-09920-y

Calabrese, A., MacInnes, J. R., Nelson, D. A., Greig, R. A., and Yevich, P. P. (1984). Effects of long-term exposure to silver or copper on growth, bioaccumulation and histopathology in the blue mussel Mytilus edulis. Mar. Environ. Res. 11, 253-274. doi: 10.1016/0141-1136(84)90038-2

Callow, M. E., and Callow, J. E. (2002). Marine biofouling: a sticky problem. Biologist 49, 10-14.

Carson, R. T., Damon, M., Johnson, L. T., and Gonzalez, J. A. (2009). Conceptual issues indesigning a policy to phase out metal-based antifouling paints on recreational boats in San Diego Bay. J. Environ. Manag. 90, 2460-2468. doi: 10.1016/j.jenvman.2008.12.016

Cateni, F., Bonivento, P., Procida, G., Zacchigna, M., Scialino, G., and Banfi, E. (2007). Chemoenzymatic synthesis and in vitro studies on the hydrolysis of antimicrobial monoglycosyl diglycerides by pancreatic lipase. Bioorg. Med. Chem. Lett. 17, 1971-1978. doi: 10.1016/j.bmcl.2007.01.019

Chambers, L. D., Hellio, C., Stokes, K. R., Dennington, S. P., Goodes, L. R., Wood, R. J. K., et al. (2011). Investigation of Chondrus crispus as a potential source of new antifouling agents. Int. Biodeterior. Biodegradation 65, 939-946. doi: 10.1016/j.ibiod.2011.07.002

Chen, L., and Lam, J. C. W. (2017). SeaNine 211 as antifouling biocide: a coastal pollutant of emerging concern. J. Environ. Sci. 61, 68-79. doi: 10.1016/j.jes.2017. 03.040

Coglianese, M. P., and Martin, M. (1981). Individual and interactive effects of environmental stress on the embryonic development of the Pacific oyster.

\section{DATA AVAILABILITY STATEMENT}

All datasets generated for this study are included in the article/supplementary material.

\section{AUTHOR CONTRIBUTIONS}

$\mathrm{EP}, \mathrm{CH}, \mathrm{BG}$, and EB-B: conceived and designed the experiments. EP and RT: performed the experiments. EP, LS, GS, and EB-B: analyzed the data. EP, GS, CH, BG, RP, and EB-B: contributed reagents, materials, and analysis tools. $\mathrm{EP}, \mathrm{CH}, \mathrm{BG}, \mathrm{RP}$, and $\mathrm{EB}-\mathrm{B}$ : wrote the manuscript.

\section{FUNDING}

This research was funded by CNPq and FAPERJ. This work was supported financially by the Fundação de Amparo à Pesquisa do Estado do Rio de Janeiro (FAPERJ; protocol 231672). BG, RP, GS, and EB-B benefit from Research Productivity fellowships awarded by CNPq.

\section{ACKNOWLEDGMENTS}

We are grateful to Dr. Maria Thereza Menezes de Széchy from Universidade Federal do Rio de Janeiro (UFRJ) for her help in setting up the collection of Sargassum vulgare.

Crassostrea gigas. Mar. Environ. Res. 5, 13-27. doi: 10.1016/0141-1136(81) 90019-2

Da Gama, B. A. P., Carvalho, A. G. V., Weidner, K., Soares, A. R., Coutinho, R., Fleury, B. G., et al. (2008). Antifouling activity of natural products from Brazilian seaweeds. Bot. Mar. 51, 191-201. doi: 10.1515/znc-20021-227

Da Gama, B. A. P., Plouguerné, E., and Pereira, R. C. (2014). The antifouling defence mechanisms of marine macroalgae. Adv. Bot. Res. 71, 413-440. doi: 10.1016/B978-0-12-408062-1.00014-7

Dafforn, K. A., Lewis, J. A., and Johnston, E. L. (2011). Antifouling strategies: history and regulation, ecological impacts and mitigation. Mar. Pollut. Bull. 62, 453-465. doi: 10.1016/j.marpolbul.2011.01.012

de Souza, L. M., Sassaki, G. L., Romanos, M. T., and Barreto-Bergter, E. (2012). Structural characterization and anti-HSV-1 and HSV-2 activity of glycolipids from the marine algae Osmundaria obtusiloba isolated from Southeastern Brazilian coast. Mar. Drugs 10, 918-931. doi: 10.3390/md10040918

Deal, M. S., Hay, M. E., Wilson, D., and Fenical, W. (2003). Galactolipids rather than phlorotannins as herbivore deterrents in the brown seaweed Fucus vesiculosus. Oecologia 136, 107-114. doi: 10.1007/s00442-003-1242-3

Dobretsov, S., Dahms, H. U., and Qian, P. Y. (2006). A review: inhibition of biofouling by marine microorganisms and their metabolites. Biofouling 22, 43-54. doi: 10.1080/08927010500504784

Dusane, D. H., Pawar, V. S., Nancharaiah, Y. V., Venugopalan, V. P., Kumar, A. R., and Zinjarde, S. S. (2011). Anti-biofilm potential of a glycolipid surfactant produced by a tropical marine strain of Serratia marcescens. Biofouling 27, 645-654. doi: 10.1080/08927014.2011.594883

Folch, J., Lees, M., and Sloane-Stanley, G. H. (1957). A simple method for the isolation and purification of total lipids from animal tissues. J. Biol. Chem. 226, 497-509.

Gould, E., Thompson, R. J., Buckley, L. J., Rusanowsky, D., and Sennefelder, G. R. (1988). Uptake and effects of copper and cadmium on the gonad of the scallop 
Placopecten magellanicus: concurrent metal exposure. Mar. Biol. 97, 217-223. doi: 10.1007/BF00391305

Guillard, R. R. L., and Ryther, J. H. (1962). Studies of marine planktonic diatoms. I. Cyclotella nana hustedt and Detonula confervacea Cleve. Can. J. Microbiol. 8, 229-239. doi: 10.1139/m62-029

Hanssen, K. Ø, Cervin, G., Trepos, R., Petitbois, J., Haug, T., Hansen, E., et al. (2014). The bromotyrosine derivative ianthelline isolated from the Arctic marine sponge Stryphnus fortis inhibits marine micro- and macrobiofouling. Mar. Biotechnol. 16, 684-694. doi: 10.1007/s10126-014-9583-y

Hellio, C., Trepos, R., Aguila-Ramirez, R. N., and Hernandez-Guerrero, J. C. (2015). "Protocol for assessing antifouling activities of macroalgal extract," in Natural Products From Marine Algae. Methods in Molecular Biology, eds D. Stengel, and S. Connan (New York, NY: Humana Press), 421-435. doi: 10.1007/ 978-1-4939-2684-8_27

Holmstrom, C., and Kjelleberg, S. (1994). The effect of external biological factors on settlement of marine invertebrate and new antifouling technology. Biofouling 8 , 147-160. doi: 10.1080/08927019409378269

Hosikian, A., Lim, S., Ronald, H., and Danquah, M. K. (2010). Chlorophyll extraction from microalgae: a review on the process engineering aspects. Int. J. Chem. Eng. Appl. 2010:11. doi: 10.1155/2010/391632

Jacobson, A. H., and Willingham, G. L. (2000). Sea-nine antifoulant: an environmentally acceptable alternative to organotin antifoulants. Sci. Total Environ. 258, 103-110. doi: 10.1016/S0048-9697(00)00511-8

Jellali, R., Campistron, I., Pasetto, P., Laguerre, A., Gohier, F., Hellio, C., et al. (2013). Antifouling activity of novel polyisoprene-based coatings made from photocurable natural rubber derived oligomers. Prog. Org. Coat. 76, 1203-1214.

Kalisch, B., Dörmann, P., and Hölzl, G. (2016). "DGDG and Glycolipids in Plants and Algae," in Lipids in Plant and Algae Development. Subcellular Biochemistry, Vol. 86, eds Y. Nakamura, and Y. Li-Beisson (Cham: Springer).

Kim, N. S., Hong, S. H., An, J. G., Shin, K. H., and Shim, W. J. (2015). Distribution of butyltins and alternative antifouling biocides in sediments from shipping and ship-building areas in South Korea. Mar. Pollut. Bull. 95, 484-490. doi: 10.1016/j.marpolbul.2015.03.010

Kim, Y., Kim, E. H., Lee, C., Kim, M. H., and Rho, J. R. (2007). Two new monogalactosyl diacylglycerols from brown alga Sargassum thunbergii. Lipids 42, 395-399. doi: 10.1007/s11745-007-3035-7

Kiran, G. S., Sabarathnam, B., Thajuddin, N., and Selvin, J. (2014). Production of glycolipid biosurfactant from sponge-associated marine actinobacterium Brachybacterium paraconglomeratum MSA21. J. Surfactants. Deterg. 17, 531542. doi: 10.1007/s11743-014-1564-7

Kobayashi, K. (2016). Role of membrane glycerolipids in photosynthesis, thylakoid biogenesis and chloroplast development. J. Plant. Res. 129, 565-580. doi: 10. 1007/s10265-016-0827-y

Lee, H. H., and Xu, C. H. (1984). Effects of metals on sea urchin development: a rapid bioassay. Mar. Pollut. Bull. 15, 18-21. doi: 10.1016/0025-326X(84)904 18-1

Leonardi, P., Miravalles, A., Faugeron, S., Flores, V., Beltran, J., and Correa, J. (2006). Diversity, phenomenology and epidemiology of epiphytism in farmed Gracilaria chilensis (Rhodophyta) in northern Chile. Eur. J. Phycol. 41, 247-257. doi: $10.1080 / 09670260600645659$

Lussier, S. M., Gentile, J. H., and Walker, J. (1985). Acute and chronic effects of heavy metals and cyanide on Mysidopsis bahia (Crustacea: Mysidacea). Aq. Toxicol. 7, 25-35. doi: 10.1016/0166-445X(85)90034-7

MacDonald, J. M., Shields, J. D., and Zimmer-Faust, R. K. (1988). Acute toxicities of eleven metals to early life-history stages of the yellow crab Cancer anthonyi. Mar. Biol. 98, 201-207. doi: 10.1007/BF00391195

Maréchal, J. P., Culioli, G., Hellio, C., Thomas-Guyon, H., Callow, M. E., Clare, A. S., et al. (2004). Seasonal variation in antifouling activity of crude extracts of the brown alga Bifurcaria bifurcata (Cystoseiraceae) against cyprids of Balanus amphitrite and the marine bacteria Cobetia marina and Pseudoalteromonas haloplanktis. J. Exp. Mar. Biol. Ecol. 313, 47-62. doi: 10.1016/j.jembe.2004.0 7.016

Martin, M., Osborn, K. E., Billig, P., and Glickstein, N. (1981). Toxicities of ten metals to Crassostrea gigas and Mytilus edulis embryos and Cancer magister larvae. Mar. Pollut. Bull. 12, 305-308. doi: 10.1016/0025-326X(81)90081-3

Muñoz, J., and Fotedar, R. (2009). Epiphytism of Gracilaria cliftonii (Withell. Millar \& Kraft) from Western Australia. J. Appl. Phycol. 22, 371-379. doi: 10.1007/ s10811-009-9469-y
Plouguerné, E., Da Gama, B. A. P., Pereira, R. C., and Barreto-Bergter, E. (2014). Glycolipids from seaweeds and their potential biotechnological applications. Front. Cell. Infect. Microbiol. 4:174. doi: 10.3389/fcimb.2014.00174

Plouguerné, E., Ioannou, E., Georgantea, P., Vagias, C., Roussis, V., Hellio, C., et al. (2010). Anti-microfouling activity of lipidic metabolites from the invasive brown alga Sargassum muticum (Yendo) Fensholt. Mar. Biotechnol. 12, 52-61. doi: 10.1007/s10126-009-9199-9

Qian, P. Y., Lau, S. C. K., Dahms, H. U., Dobretsov, S., and Harder, T. (2007). Marine biofilms as mediators of colonization by marine macroorganisms: implications for antifouling and aquaculture. Mar. Biotechnol. 9, 399-410. doi: 10.1007/s10126-007-9001-9

Readman, J. W. (2006). "Development, occurrence and regulation of antifouling paint biocides: historical review and future trends," in The Handbook of Environmental Chemistry, Vol. 5, ed. I. Konstantinou (Berlin Heidelberg: Springer-Verlag), 1-15. doi: 10.1007/698_5_047

Sapozhnikova, Y., Wirth, E., Schiff, K., and Fulton, M. (2013). Antifouling biocides in water and sediments from California marinas. Mar. Pollut. Bull. 69, 189-194. doi: 10.1016/j.marpolbul.2013.01.039

Silkina, A., Bazes, A., Vouve, F., Tilly, V. L., Douzenel, P., Mouget, J. L., et al. (2009). Antifouling activity of macroalgal extracts on Fragilaria pinnata (Bacillariophyceae): a comparison with diuron. Aq. Toxicol. 94, 245-254. doi: 10.1016/j.aquatox.2009.07.004

Sjollema, S. B., Martínez García, G., Van der Geest, H. G., Kraak, M. H. S., Booij, P., Vethaak, A. D., et al. (2014). Hazard and risk of herbicides for marine microalgae. Environ. Pollut. 187, 106-111. doi: 10.1016/j.envpol.2013.12.019

Slattery, M., and Lesser, M. P. (2014). Allelopathy in the tropical alga Lobophora variegata (Phaeophyceae): mechanistic basis for a phase shift on mesophotic coral reefs? J. Phycol. 50, 493-505. doi: 10.1111/jpy.12160

Son, B. W., Cho, Y. J., and Kim, N. K. (1992). Choi, H.D. New glyceroglycolipids from the brown alga Sargassum thunbergii. Bull. Korean. Chem. Soc. 13, 584-586.

Stromgren, T., and Nielsen, M. V. (1991). Spawning frequency, growth and mortality of Mytilus edulis larvae, exposed to copper and diesel oil. Aquat. Toxicol. 21, 171-180. doi: 10.1016/0166-445X(91)90071-G

Trepos, R., Cervin, G., Hellio, C., Pavia, H., Stensen, W., Stensvåg, K., et al. (2014). Antifouling compounds from the sub-arctic ascidian Synoicum pulmonaria: synoxazolidinones A and C. Pulmonarins A and B, and synthetic analogues. J. Nat. Prod. 77, 2105-2113. doi: 10.1021/np5005032

Tsoukatou, M., Hellio, C., Vagias, C., Harvala, C., and Roussis, V. (2002). Chemical defense and antifouling activity of three Mediterranean sponges of the genus Ircinia. Z. Naturforsch. 57, 161-171. doi: 10.1515/znc-2002-1-227

Tsunemasa, N., and Yamazaki, H. (2014). Concentration of antifouling biocides and metals in sediment core samples in the northern part of Hiroshima Bay. Int. J. Mol. Sci. 15, 9991-10004. doi: 10.3390/ijms15069991

Turner, A. (2010). Marine pollution from antifouling paint particles. Mar. Pollut. Bull. 60, 159-171. doi: 10.1016/j.marpolbul.2009.12.004

Wahl, M. (1989). Marine epibiosis. Fouling and antifouling: some basic aspects. Mar. Ecol. Prog. Ser. 58, 175-189. doi: 10.3354/meps058175

Zhang, J., Li, C., Yu, G., and Guan, H. (2014). Total synthesis and structureactivity relationship of glycoglycerolipids from marine organisms. Mar. Drugs. 12, 3634-3659. doi: 10.3390/md12063634

Zhou, A., Debbab, A., Wray, V., Lin, W., Schulz, B., Trepos, R., et al. (2014). Marine bacterial inhibitors from the sponge derived fungus Aspergillus sp. Tetrahedron Lett. 55, 2789-2792. doi: 10.1016/j.tetlet.2014.02.062

Zhou, J. L. (2008). Occurrence and persistence of antifouling biocide irgarol 1051 and its main metabolite in the coastal waters of Southern England. Sci. Total. Environ. 406, 239-246. doi: 10.1016/j.scitotenv.2008.07.049

Conflict of Interest: The authors declare that the research was conducted in the absence of any commercial or financial relationships that could be construed as a potential conflict of interest.

Copyright ( 2020 Plouguerné, de Souza, Sassaki, Hellio, Trepos, da Gama, Pereira and Barreto-Bergter. This is an open-access article distributed under the terms of the Creative Commons Attribution License (CC BY). The use, distribution or reproduction in other forums is permitted, provided the original author(s) and the copyright owner(s) are credited and that the original publication in this journal is cited, in accordance with accepted academic practice. No use, distribution or reproduction is permitted which does not comply with these terms. 